\title{
A screen for transcription factor targets of Glycogen Synthase Kinase-3 highlights an inverse correlation of NFKB and Androgen Receptor Signaling in Prostate Cancer
}

\author{
Victor M. Campa ${ }^{1,3}$, Eder Baltziskueta ${ }^{1}$, Nora Bengoa-Vergniory ${ }^{1}$, Irantzu Gorroño- \\ Etxebarria ${ }^{1}$, Radosław Wesołowski ${ }^{1}$, Jonathan Waxman ${ }^{2}$, Robert M. Kypta ${ }^{1,2}$ \\ ${ }^{1}$ Cell Biology and Stem Cells Unit, CIC bioGUNE, Spain \\ 2 Department of Surgery and Cancer, Imperial College London, UK \\ 3 Present address: Instituto de Biomedicina y Biotecnología de Cantabria (IBBTEC), CSIC-Universidad de Cantabria, \\ Santander 39011, Spain
}

Correspondence to:

Dr. Robert M. Kypta, e-mail: rkypta@cicbiogune.es, r.kypta@imperial.ac.uk

Keywords: prostate cancer, glycogen synthase kinase-3, androgen receptor, NFKB transcription factor, Wnt signaling

Received: July 11, $2014 \quad$ Accepted: August 02, 2014 Published: August 07, 2014

Abbreviations: GSK-3 (glycogen synthase kinase-3), AR (androgen receptor), GR (glucocorticoid receptor), CHIR (CHIR99021), BIO (BIO-Acetoxime), PS (PS1 145), NFKB (nuclear factor kappa-light-chain-enhancer of activated B cells), PCa (prostate cancer), DHT (dihydrotestosterone), TNF (tumor necrosis factor), and AP-2 (activating protein 2).

\section{ABSTRACT}

Expression of Glycogen Synthase Kinase-3 (GSK-3) is elevated in prostate cancer and its inhibition reduces prostate cancer cell proliferation, in part by reducing androgen receptor (AR) signaling. However, GSK-3 inhibition can also activate signals that promote cell proliferation and survival, which may preclude the use of GSK-3 inhibitors in the clinic. To identify such signals in prostate cancer, we screened for changes in transcription factor target DNA binding activity in GSK-3-silenced cells. Among the alterations was a reduction in AR DNA target binding, as predicted from previous studies, and an increase in NFKB DNA target binding. Consistent with the latter, gene silencing of GSK-3 or inhibition using the GSK-3 inhibitor CHIR99021 increased basal NFKB transcriptional activity. Activation of NFKB was accompanied by an increase in the level of the NFKB family member RelB. Conversely, silencing RelB reduced activation of NFKB by CHIR99021. Furthermore, the reduction of prostate cancer cell proliferation by CHIR99021 was potentiated by inhibition of NFKB signaling using the IKK inhibitor PS1145. Finally, stratification of human prostate tumor gene expression data for GSK3 revealed an inverse correlation between NFKB-dependent and androgen-dependent gene expression, consistent with the results from the transcription factor target DNA binding screen. In addition, there was a correlation between expression of androgen-repressed NFKB target genes and reduced survival of patients with metastatic prostate cancer. These findings highlight an association between GSK-3/AR and NFKB signaling and its potential clinical importance in metastatic prostate cancer.

\section{INTRODUCTION}

The protein kinase Glycogen synthase kinase-3 (GSK-3) is up-regulated in many cancers, including prostate cancer $(\mathrm{PCa})[1-3]$ and GSK-3 inhibitors reduce prostate tumor growth in vitro $[4,5]$ and in vivo [6]. $\mathrm{PCa}$ initiation and progression are uniquely dependent on the androgen receptor (AR) [7]. AR transcriptional activity is regulated by co-activator and co-repressor proteins and by posttranslational modifications, such as phosphorylation by kinases [4, 8-11], including GSK-3, which is important for AR stability, nuclear localization and transcriptional activity $[4,5,12]$. The mechanism of action of GSK-3 is however complex and contextdependent, since its overexpression in some cell types inhibits AR $[10,11]$ and there are instances where GSK-3 
inhibitors reduce proliferation of AR-negative PCa cells $[13,14]$. In addition, GSK-3 regulates other signals, such as those mediated by Wnt and $\mathrm{NF \kappa B}$, which are themselves linked [15]. Adding further complexity, there are two GSK-3 isoforms, GSK-3 $\alpha$ and GSK-3 $\beta$ that have different expression profiles in PCa [1]. Knockout studies have shown that the two isoforms generally compensate for one another [16]. However, there are examples where a single isoform has a unique or predominant function $[17,18]$. This is the case in PCa, where GSK-3 $\alpha$ is more important for maintaining AR transcriptional activity and silencing GSK-3 $\beta$ but not GSK-3 $\alpha$ reduces PKB phosphorylation [1].

In order to identify isoform-specific GSK-3 targets in $\mathrm{PCa}$, we screened for transcription factors whose binding to cognate DNA target sequences is altered upon GSK-3 silencing. We observed reduced binding to an AR target binding site upon silencing GSK-3 $\alpha$, consistent with our earlier study [1], and increased binding to an NF $\kappa$ B target-binding site in cells chronically silenced for GSK-3 $\beta$. Further analyses using PCa cell lines and tumor array data revealed a link between GSK-3 expression and an inverse correlation between $\mathrm{AR}$ and $\mathrm{NF} \kappa \mathrm{B}$ signaling pathways. GSK-3 has previously been linked to NFкB activation [19] and there are a variety of reports on the mechanisms involved. For example, GSK-3 can inhibit p65 transcriptional activity [20], increase p105 stability [21], suppress chromatin accessibility [22] and inhibit IKK phosphorylation of IкB [23]. On the other hand, there are many instances where targeted deletion of GSK-3 $\beta$ inhibits NFkB activity [24-26]. The conclusion from these apparently conflicting studies is that GSK-3 regulation of NF $\kappa \mathrm{B}$ is highly context-dependent and will only be understood by carrying out experiments using the cells and tissues of interest. The studies described in this report find that acute gene silencing and chemical inhibition of GSK-3 increase basal $\mathrm{NF} \kappa \mathrm{B}$ activity in $\mathrm{PCa}$, and that combined inhibition of GSK-3 and NFKB signaling is more effective than inhibition of each alone for reducing PCa cell proliferation.

\section{RESULTS}

\section{A screen for transcription factor targets of GSK-3 in PCa cells identifies unique and common targets of GSK-3 $\alpha$ and GSK-3 $\beta$}

In order to identify isoform-specific GSK-3 targets in $\mathrm{PCa}$, we screened for transcription factors whose binding to cognate DNA target sequences is altered upon GSK-3 silencing in 22Rv1 PCa cells. Since we previously found differences between the effects of acute and chronic silencing of GSK-3 on AR activity [1], experiments were carried out using both conditions. In the acute silencing experiments, we used nuclear extracts from cells transiently transfected with shRNAs specific for GSK-3 $\alpha$ or GSK-3 $\beta$. Acute GSK-3 $\alpha$ silencing reduced the binding activity of AR to its DNA target element (Figures 1A and B), consistent with our previous study [1]. Also in keeping with these results, silencing of GSK-3 $\alpha$ but not of GSK-3 $\beta$ reduced expression of the AR target gene TMEPA1 [27], but not of AR itself (Figure 1C). In addition, silencing GSK-3 $\alpha$ increased binding activity of activator protein 2 (AP-2) (Figure 1A), without affecting expression of TFAP2A (Figure 1C), the major AP-2 family member expressed in 22Rv1 cells, and silencing GSK-3 $\alpha$ and, to a lesser extent, GSK-3 $\beta$ increased binding activity of the glucocorticoid receptor (GR) (Figures 1A and B). We next carried out protein/DNA array screens using extracts from $22 \mathrm{Rv} 1$ cell clones stably silenced for either GSK-3 $\alpha$ or GSK-3 $\beta$. In contrast to the results from acute silencing, binding to AR target DNA was slightly increased in cells stably silenced for GSK-3 $\alpha$ (Figures 1D and F). In addition, the changes in AP-2 and GR binding activities observed upon acute silencing of GSK-3 $\alpha$ were not seen in stably silenced cells, suggesting that several changes induced upon acute silencing of GSK-3 are not maintained in stably silenced cell lines. Several other spots were reproducibly altered with stable GSK-3 $\alpha$ silencing, namely an increase in binding to the Sp1 binding site (row 11 columns 1/2), the Stat5/6 binding site (columns 13/14) and the Pbx1 binding site (row 7 columns 15/16), also observed upon acute silencing of GSK-3 $\alpha$. To address the possibility that stable inhibition of GSK-3 leads to selection for prostate cancer stem/progenitor-like cells, as was recently reported for PC3 cells [28], we measured the expression levels of three genes expressed in 22Rv1derived stem/progenitor cells, SOX2, NANOG and BCRP [29], in the 22Rv1-derived cell clones. This revealed small reductions in expression of SOX2 in both GSK3 -isoform silenced cell lines, a small increase in NANOG expression in the GSK-3 $\alpha$-silenced cell line and no change in expression of BCRP (Figure 1E). These results suggest that stable inhibition of GSK-3 isoforms does not lead to selection for prostate cancer stem/progenitor-like cells. In addition, we observed increased binding to the $\mathrm{NF} \kappa \mathrm{B}$ target DNA sequence in cells stably silenced for GSK-3 $\beta$ (Figures 1D, F), and, consistent with this, NFKBdependent transcription was increased in cell lines stably silenced for GSK-3 $\beta$ (Figure 1G).

\section{GSK-3 inhibition activates NF $\mathrm{NB}$ independently of $\beta$-catenin and $A R$}

The observation that stable but not acute silencing of GSK-3 $\beta$ increased NFKB activity prompted us to determine the effects of acute silencing on NFKB-dependent transcription. Acute silencing of single GSK-3 isoforms did not affect $\mathrm{NF \kappa B}$ transcriptional activity (Figure 2A), consistent with no change in NFKB target DNA binding 
A
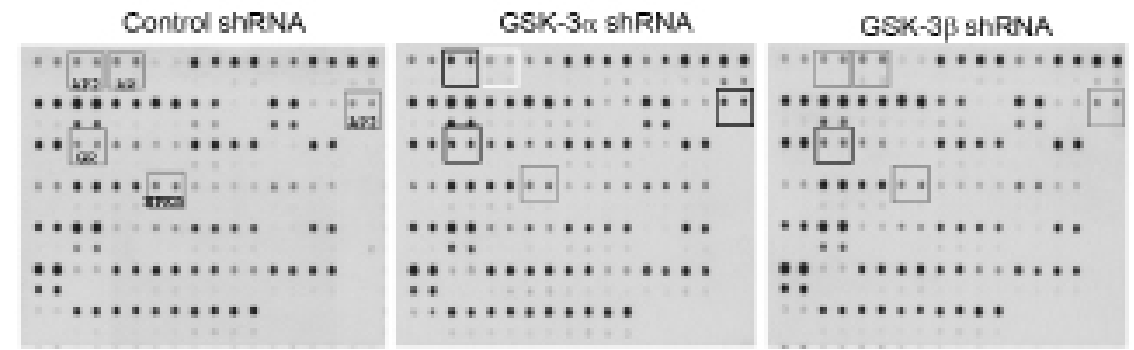

B

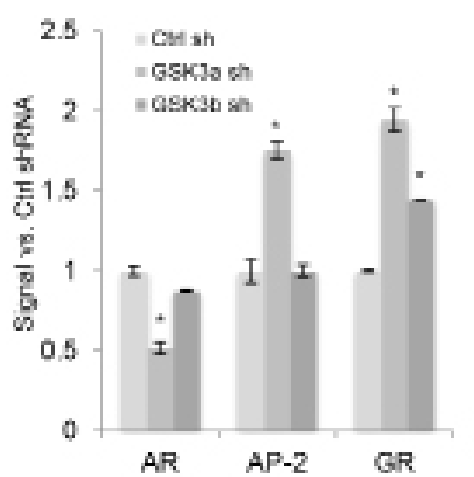

C

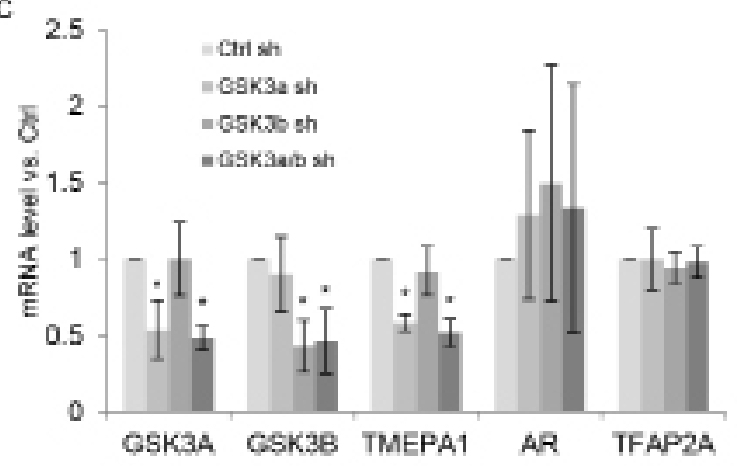

D
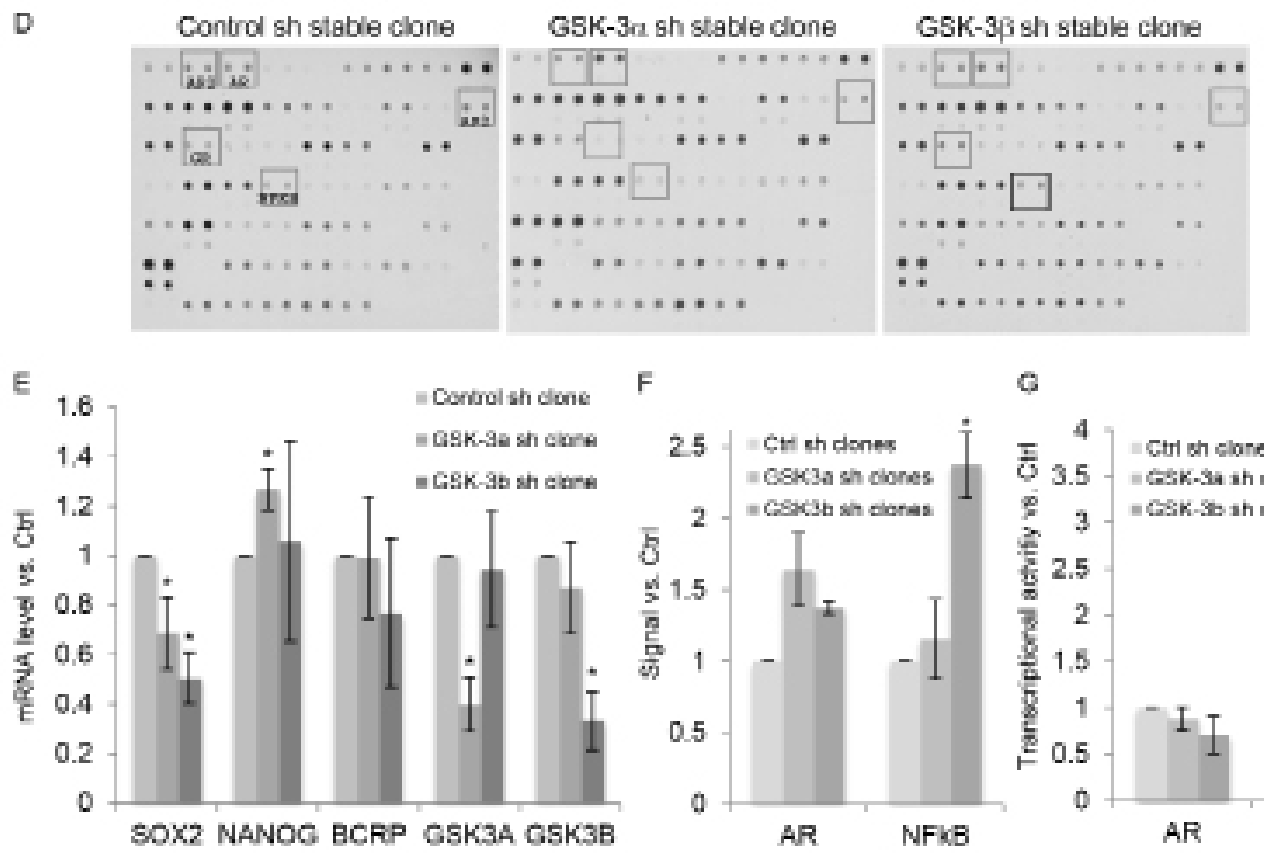

$\mathrm{F}$

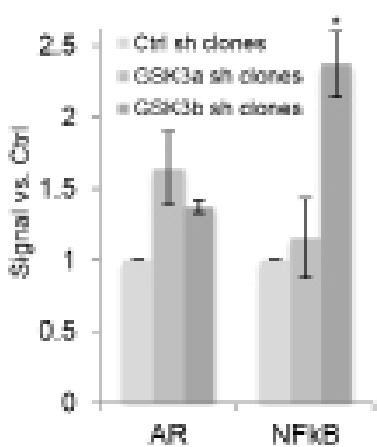

C

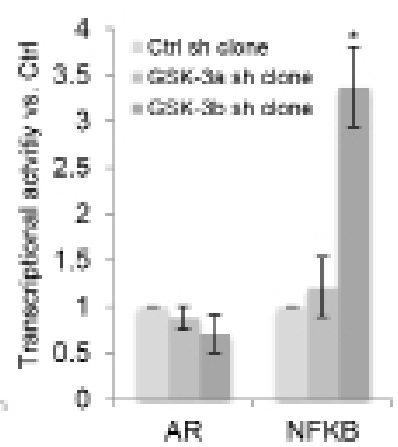

Figure 1: A screen for transcription factor targets of GSK-3 in PCa cells identifies AR and NFkB as targets of GSK-

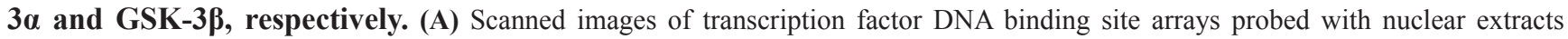
from 22Rv1 cells transiently transfected with the indicated shRNAs. The grey boxes highlight relevant transcription factor binding sites; changes in signal, compared with control shRNA-transfected cells, are indicated in black (increased binding to AP-2 and GR binding sites) and white (reduced binding to AR binding site). (B) Average signals for the indicated binding sites from two independent experiments in duplicate, relative to control shRNA; ${ }^{*} \mathrm{p}<0.05$, compared to control shRNA. (C) 22Rv1 cells transfected with indicated shRNA plasmids were selected with puromycin for $72 \mathrm{~h}$ and the expression of GSK3A, GSK3B, TMEPA1, AR and TFAP2A mRNAs determined by q-PCR; $* \mathrm{p}<0.05$ compared to control shRNA (Ctrl sh); $\mathrm{n}=3$. (D) Scanned images of representative transcription factor DNA binding site arrays probed with nuclear extracts from 22Rv1 cell clones expressing control, GSK-3 $\alpha$ (clone 3) or GSK-3 $\beta$ (clone 18) shRNAs. Grey boxes highlight relevant transcription factor binding sites; black box shows increased signal at the NFkB binding site. (E) Analysis for the mRNA expression levels of SOX2, NANOG, BCRP1, GSK3A and GSK3B in 22Rv1 cell clones expressing control, GSK-3 $\alpha$ (clone 3 ) or GSK-3 $\beta$ (clone 18) shRNAs was determined by q-PCR; ${ }^{*} \mathrm{p}<0.05$ compared to control shRNA (Ctrl sh); $\mathrm{n}=3$. (F) Average signals for the indicated binding sites for two independent cell clones for each in duplicate, relative to control cells; * $\mathrm{p}<0.05$, compared to control. (G) Gene reporter assays using extracts from $22 \mathrm{Rv} 1$ cell clones as in D. Basal NFkB activity was measured using NFkB-luciferase and AR activity was measured using MMTV-luciferase in cells cultured in charcoal-stripped medium with $10^{-8} \mathrm{M}$ DHT. Renilla was used to normalize for transfection efficiency. Graphs show luciferase/renilla values, relative to control cells; $* \mathrm{p}<0.05$, compared to control; $\mathrm{n}=2$. 
A

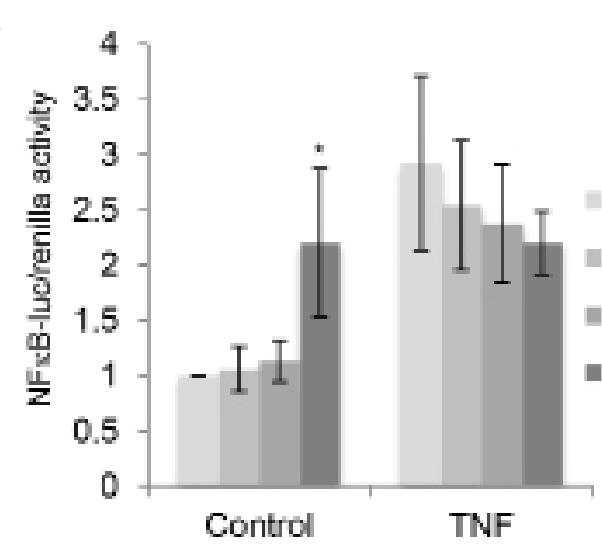

$\mathrm{C}$

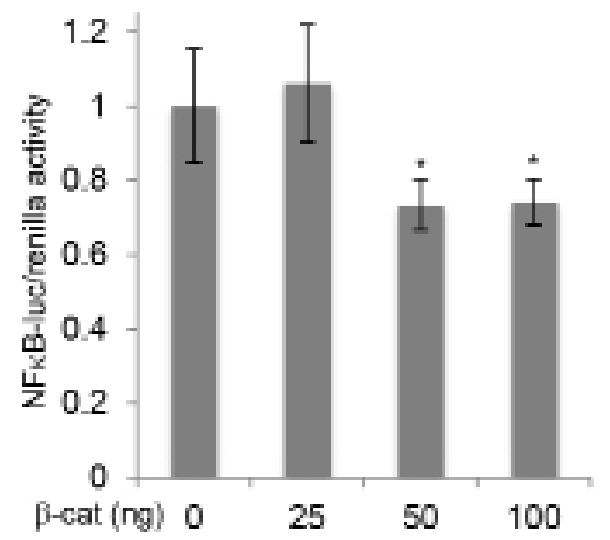

E

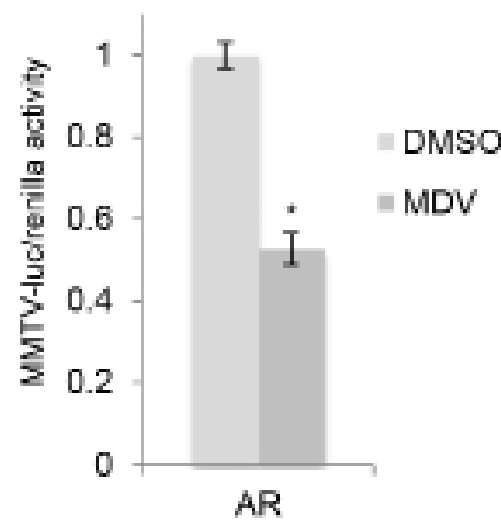

B

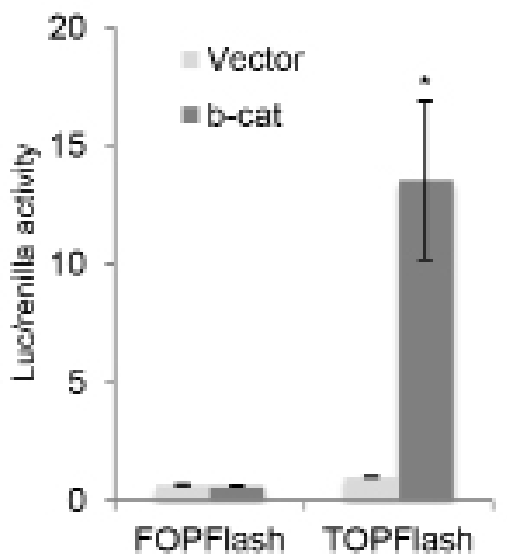

D
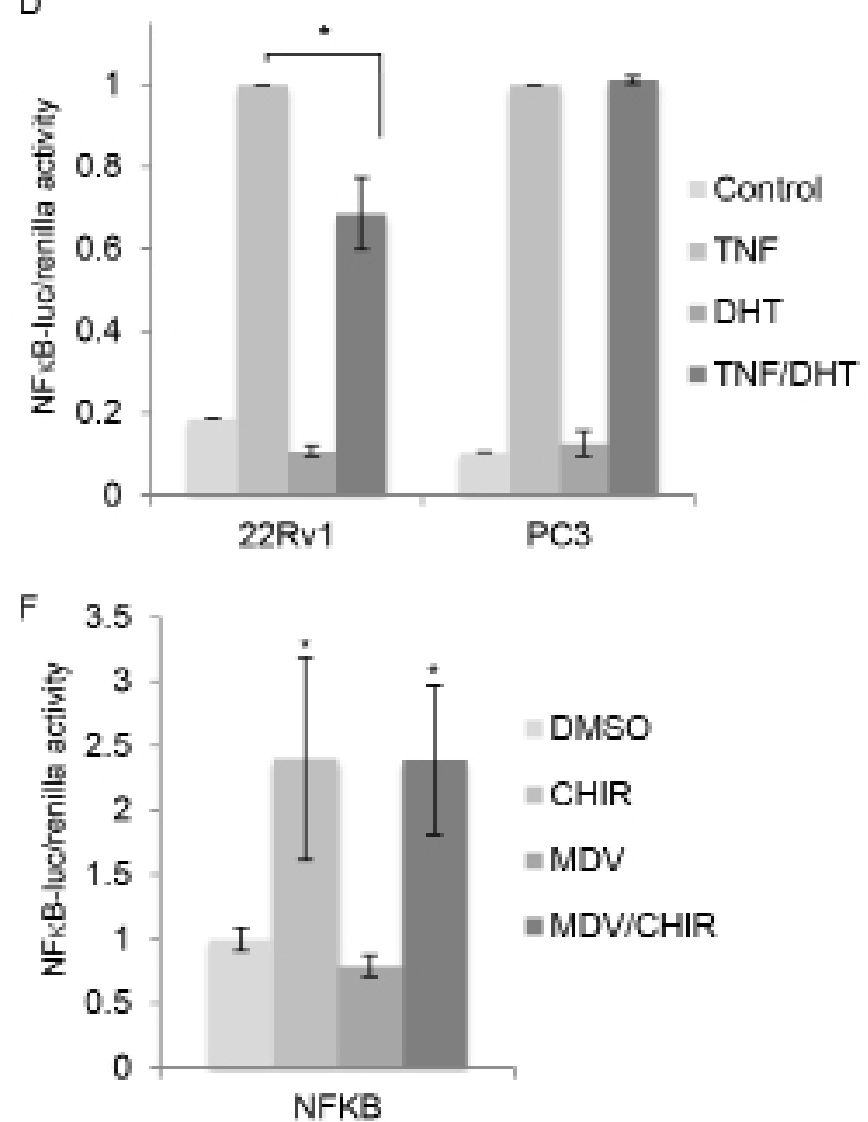

Figure 2: GSK-3 inhibition activates NFKB independently of $\beta$-catenin and AR. (A) Gene reporter assays using extracts from 22Rv1 cells transfected with control shRNA (Ctrl sh) or shRNAs targeting GSK-3 $\alpha$ (GSK3a sh), GSK-3 $\beta$ (GSK3b sh) or both GSK3a/b sh), and plasmids encoding NFkB-luciferase and renilla (pRL-tk), and treated with TNF (20 nM) or vehicle for $6 \mathrm{~h}$. Graph shows luciferase/ renilla ratios $18 \mathrm{~h}$ after transfection normalized to $\mathrm{Ctrl} \operatorname{sh} ;{ }^{*} \mathrm{p}<0.05 \mathrm{vs.} \mathrm{Ctrl} \mathrm{sh} ; \mathrm{n}=4$. (B) Gene reporter assays using extracts from $22 \mathrm{Rv} 1$ cells transfected with plasmid encoding $\beta$-catenin or empty vector, Super8xTOPFlash or Super8xFOPFlash and renilla. Graph shows luciferase/renilla ratios normalized to vector; ${ }^{*} p<0.01$ vs. vector. (C) Gene reporter assays using extracts from $22 \mathrm{Rv} 1$ cells transfected with the indicated amounts of plasmid encoding $\beta$-catenin (total amount brought to $200 \mathrm{ng}$ with empty vector), and plasmids encoding $\mathrm{NF \kappa B}$-luciferase and renilla. Graph shows luciferase/renilla ratios, normalized to 0 ng $\beta$-catenin plasmid; * $\mathrm{p}<0.05$ vs. vector. (D) Gene reporter assays using extracts from 22Rv1 cells and PC3 cells transfected with NFKB-Luc and renilla. After transfection, cells were cultured for $18 \mathrm{~h}$ in phenol red-free medium containing charcoal-stripped serum with or without $10 \mathrm{nM}$ DHT and then treated with $20 \mathrm{nM}$ TNF for $6 \mathrm{~h}$ before measuring luciferase activities. Graph shows luciferase/renilla ratios; TNF-induced activity is set to $100 \%$ in each cell line; * $\mathrm{p}<0.05 ; \mathrm{n}=3$ (22Rv1), $\mathrm{n}=2$ (PC3). (E) Gene reporter assays using extracts from 22Rv1 cells transfected with MMTV-luc and renilla, treated with carrier (DMSO) or the AR antagonist $10 \mathrm{uM} \mathrm{MDV3100} \mathrm{(MDV)} \mathrm{and} \mathrm{AR} \mathrm{activity} \mathrm{determined} \mathrm{as} \mathrm{in} \mathrm{Figure} \mathrm{1F;} \mathrm{*p}<0.05$ vs. control; $\mathrm{n}=2$. (F) Gene reporter assays using extracts from 22Rv1 cells transfected with plasmids encoding NFкB-luciferase and renilla and treated with carrier (DMSO), 5 uM CHIR99021 (CHIR) and 10 uM MDV3100 (MDV), as indicated. Graph shows luciferase/renilla ratios normalized to DMSO; * $\mathrm{p}<0.05$ vs. DMSO; $\mathrm{n}=2$. 
being observed (Figure 1A and data not shown). However, silencing of both GSK-3 isoforms together modestly but significantly increased basal $\mathrm{NF} \kappa \mathrm{B}$ transcriptional activity (Figure 2A). In addition, NF $\kappa$ B transcriptional activity was increased by treatment of cells with the specific GSK-3 inhibitor CHIR99021 [30] (see Figure 2F). In summary, chronic silencing of GSK-3 $\beta$ and acute inhibition of GSK-3 $\alpha / \beta$ led to activation of $\mathrm{NF} \kappa \mathrm{B}$, as detected by increased DNA target binding and transcriptional activity. We therefore decided to explore the effects of GSK-3 inhibition on NFkB signaling in more detail.

Since silencing of both GSK-3 isoforms together also activates $\mathrm{Wnt} / \beta$-catenin signaling in $22 \mathrm{Rv} 1$ cells [1], we wished to determine if stabilization of $\beta$-catenin was responsible for the observed activation of NFאB. Cells were transfected with a plasmid encoding stabilized $\beta$-catenin, which increased $\beta$-catenin/Tcf-dependent transcription as expected (Figure 2B). $\beta$-catenin inhibited NFкBdependent transcription (Figure 2C), suggesting that the effect of GSK-3 inhibition on NFKB is not mediated by $\beta$-catenin. In addition to increasing basal NFkB activity, GSK-3 inhibitors reduce AR-dependent transcription [4]. Given previous reports that androgens inhibit NFאB [31, 32], we hypothesized that GSK-3 inhibition leads to NFкB activation by inhibiting AR. To test this possibility, we first examined the effect of AR activation on NFאB activation by Tumor Necrosis Factor (TNF). Cells were stimulated with TNF in the presence or absence of the AR ligand DHT. DHT treatment reduced TNF activation of NF $\kappa B$ in $22 \mathrm{Rv} 1$ cells (Figure 2D) and, to a lesser extent, in LNCaP cells (data not shown), but not in PC3 cells, which do not express AR (Figure 2D). These results suggest that AR could play a role in the activation of NFKB upon GSK-3 inhibition. To determine the impact of AR on GSK-3 inhibitor-mediated activation of $\mathrm{NF} \kappa \mathrm{B}$, gene reporter assays were carried out in the presence of the AR antagonist MDV3100. As expected, MDV3100 inhibited AR transcriptional activity (Figure 2E). However, it did not affect NFאB activation by CHIR99021 (Figure 2F), suggesting that the effects of GSK-3 on NFאB are not mediated via AR.

\section{Inhibition of GSK-3 activates NF $\mathrm{B}$ via RelB}

$\mathrm{NF} \kappa \mathrm{B}$ consists of a family of transcription factors whose subunits p65 (RelA), RelB, c-Rel, and p50 and p52, generated from the precursors p105 and p100, respectively, form dimers that regulate gene expression. I $\kappa \mathrm{B}$ proteins sequester $\mathrm{NF} \kappa \mathrm{B}$ dimers in the cytoplasm and activation of $\mathrm{I} \kappa \mathrm{B}$ kinase (IKK) results in $\mathrm{I} \kappa \mathrm{B}$ degradation

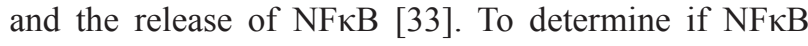
activation upon GSK-3 inhibition involves IкB, we used the Gal4-p65/Gal4-luc system [34], in which a fusion protein formed by the Gal4 DNA-binding domain and the p65 transactivation domain drives expression of Gal4responsive luciferase independently of $\mathrm{I} \kappa \mathrm{B}$. Treatment of 22Rv1 cells with CHIR99021 or the unrelated GSK-3 inhibitor BIO-Acetoxime (BIO) increased p65-Gal4 activity (Figure 3A), suggesting that GSK-3 inhibition

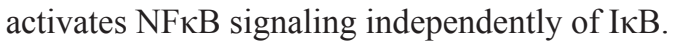

To determine if the effects of GSK-3 inhibition involved changes in $\mathrm{NF} \kappa \mathrm{B}$ family proteins, we next examined their expression levels by western blotting. Silencing of both GSK-3 isoforms together did not significantly affect most NFKB family members, although there was a trend for a reduction in the p100/p52 ratio. However, silencing GSK-3 did result in a small but significant increase in RelB (Figure 3B). In support of the gene silencing results, CHIR99021 also increased RelB levels (Figure 3C). Since GSK-3 regulates the subcellular localization of many proteins, we examined the effects of GSK-3 silencing on the localization of p100/52 and p65 (RelB could not be readily detected using the available antibodies). P100/52 was found mostly in the nucleus (Figure 3D) and p65 mostly in the cytoplasm (Figure 3E), and neither one was affected by GSK-3 silencing. Changes in p65 were also not detected in cells treated with CHIR99021 (Figure 3F). In contrast, treatment of 22Rv1 cells with TNF induced nuclear translocation of p65 (Figure 3G). Together, these results raise the possibility that activation of $\mathrm{NF \kappa B}$ upon inhibition of GSK-3 results from an increase in RelB. To investigate the role of RelB, gene reporter assays were carried out in 22Rv1 cells silenced for p65, RelB and c-Rel [35] (Figure 3H). Silencing RelB and, to a lesser extent p65, but not c-Rel, reduced CHIR99021-mediated activation of NFאB (Figure 3I), indicating that RelB plays a predominant role in the response to CHIR99021.

\section{Inhibition of NFKB potentiates the inhibitory effect of CHIR99021 on PCa cell proliferation}

Since activation of NFkB promotes cancer cell survival, we hypothesized that combined inhibition of GSK-3 and NFKB would inhibit proliferation in $\mathrm{PCa}$ cells. To test this possibility, we treated $22 \mathrm{Rv} 1$ cells with CHIR99021 to inhibit GSK-3 and PS1145 to inhibit NFKB signaling. As expected, given the low basal NFKB activity in 22Rv1 cells, PS1145 alone had no significant effect on cell number (Figure 4A). However, PS1145 potentiated the effects of CHIR99021, consistent with our hypothesis. The activities of the inhibitors were confirmed using gene reporter assays: CHIR99021 increased $\beta$-catenin activity (Figure 4B) and PS1145 inhibited TNF-induced NFאB activation (Figure 4C). Since GSK-3 inhibition represses AR signaling, we also tested the effects of combined inhibition of GSK-3, NFKB and AR on cell proliferation using MDV3100. In these experiments we used a dose of CHIR99021 that had no significant effect on proliferation when used alone (Figure 4D). As expected, MDV3100 reduced 22Rv1 cell proliferation and this effect was slightly enhanced by CHIR99021. Importantly, combined treatment of cells with MDV3100, CHIR99021 and PS1145 further reduced cell number (Figure 4D). We also 
A

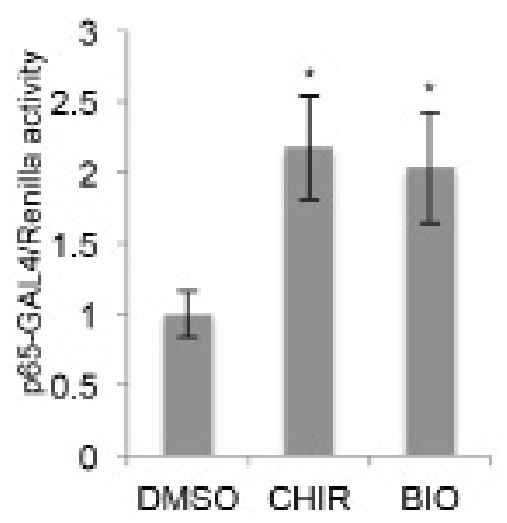

B
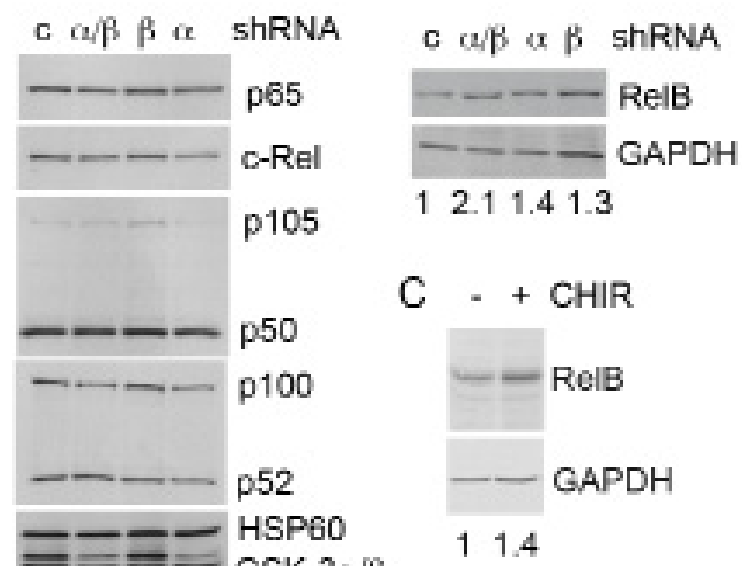

D

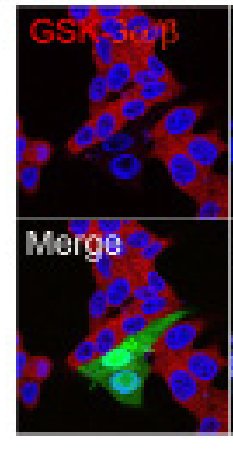

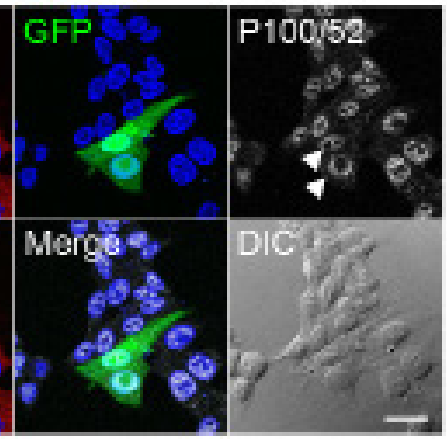

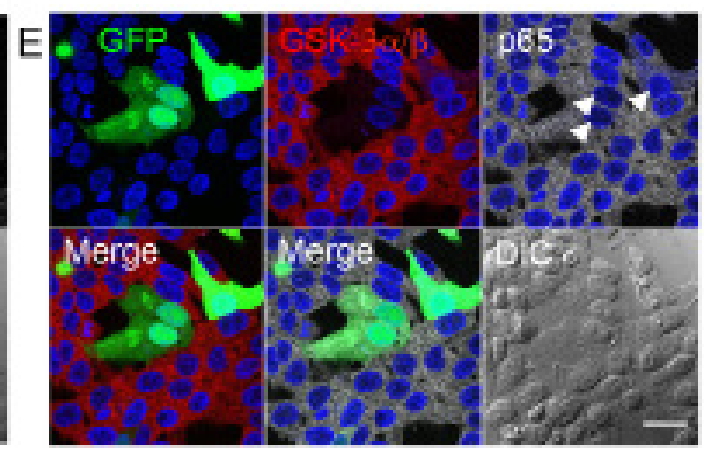

$\mathrm{F}$
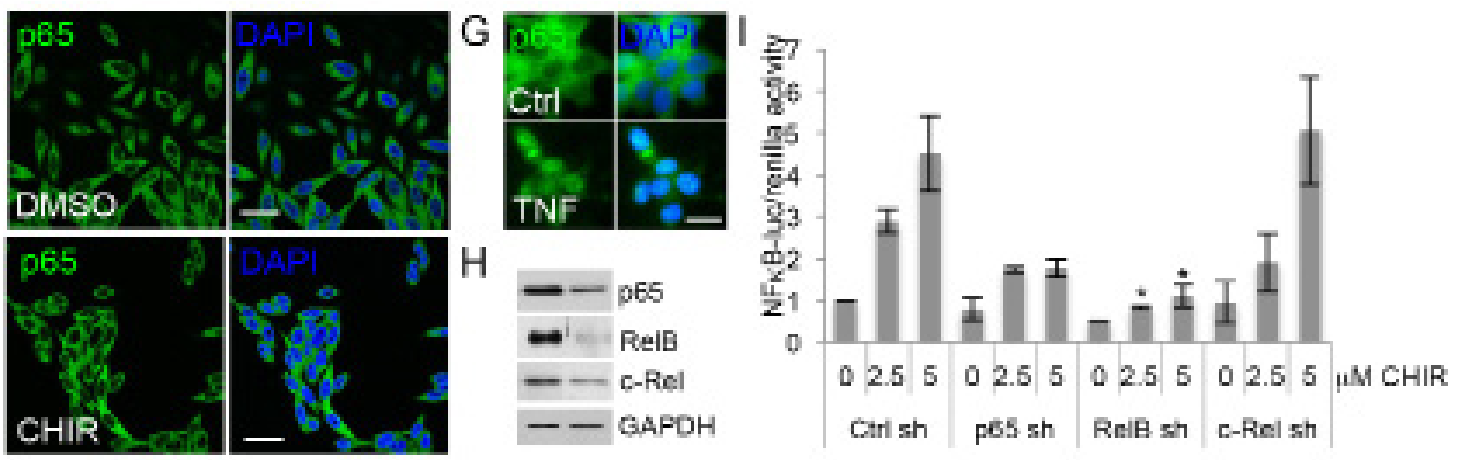

Figure 3: Inhibition of GSK-3 activates NFKB via RelB. (A) Gene reporter assays using extracts from $22 \mathrm{Rv} 1$ cells transfected with plasmids encoding p65-Gal4 Gal4-Luc, renilla and treated with vehicle (DMSO) or 5 uM CHIR99021 (CHIR) or 2.5 uM BIO-Acetoxime (BIO). Graph shows luciferase/renilla ratios normalized to DMSO; $* \mathrm{p}<0.05$ vs. DMSO; $\mathrm{n}=2$. (B) Western blots of extracts from $22 \mathrm{Rv} 1$ cells transfected with control shRNA (c) or shRNAs targeting GSK-3 $\alpha(\alpha)$, GSK-3 $\beta(\beta)$ or both isoforms $(\alpha / \beta)$, selected with puromycin for $72 \mathrm{~h}$ and probed for the indicated NFKB family proteins and HSP60 and GAPDH as loading controls. Numbers below the GAPDH blot indicate relative RelB signal normalized to GAPDH. Densitometry analysis (ImageJ) from 3 experiments indicated that silencing both GSK-3 isoforms together increased RelB 1.6 to 2.1-fold, compared to control shRNA ( $<$ 0.05). (C) Western blots of extracts from 22Rv1 cells treated with $2.5 \mathrm{uM} \mathrm{CHIR99021} \mathrm{(CHIR)} \mathrm{or} \mathrm{vehicle} \mathrm{(DMSO)} \mathrm{for} 16 \mathrm{~h}$ were probed for RelB and GAPDH as a loading control. Densitometry analysis from 3 experiments indicated that RelB was 1.4 to 2.3-fold higher in CHIR99021-treated cells than in DMSO-treated cells $(\mathrm{p}<0.05)$. (D, E) Immunostaining for GSK-3 $\alpha$ and GSK-3 $\beta$ (red) and p100/p52 (D) or p65 (E) (white) in 22Rv1 cells transfected with shRNAs to silence both GSK-3 isoforms and GFP plasmid (green) to visualize transfected cells. DAPI staining of nuclei is shown in blue. Arrows indicate cells silenced for GSK-3; scale bars $25 \mu \mathrm{m}$. (F) Immunostaining for p65 (green) in 22Rv1 cells treated with vehicle (DMSO) or CHIR99021 (CHIR) for $16 \mathrm{~h}$. DAPI staining of nuclei is shown in blue; scale bar $25 \mu \mathrm{m}$. (G) Immunostaining for p65 (green) in 22Rv1 cells with vehicle (Ctrl) or TNF for $3 \mathrm{~h}$. DAPI staining of nuclei is shown in blue; scale bar $62.5 \mu \mathrm{m}$. (H) Western blots of extracts from 22Rv1 cells transfected with control (left) or the indicated shRNA plasmid (right), selected with puromycin for $72 \mathrm{~h}$ and probed for p65, RelB and c-Rel; GAPDH was used as a loading control (blot shown is for RelB shRNA). (I) Gene reporter assays using extracts from 22Rv1 cells transfected with control (Ctrl), p65, RelB and c-Rel shRNAs, selected with puromycin for $72 \mathrm{~h}$, then transfected with NFkB-luciferase and renilla and treated with DMSO or CHIR99021 at $2.5 \mathrm{uM}$ and $5 \mathrm{uM}$. Graph shows luciferase/renilla ratios normalized to DMSO in Ctrl cells; * $\mathrm{p}<0.05$ vs. Ctrl sh at the same dose of CHIR99021; $\mathrm{n}=2$. 
A
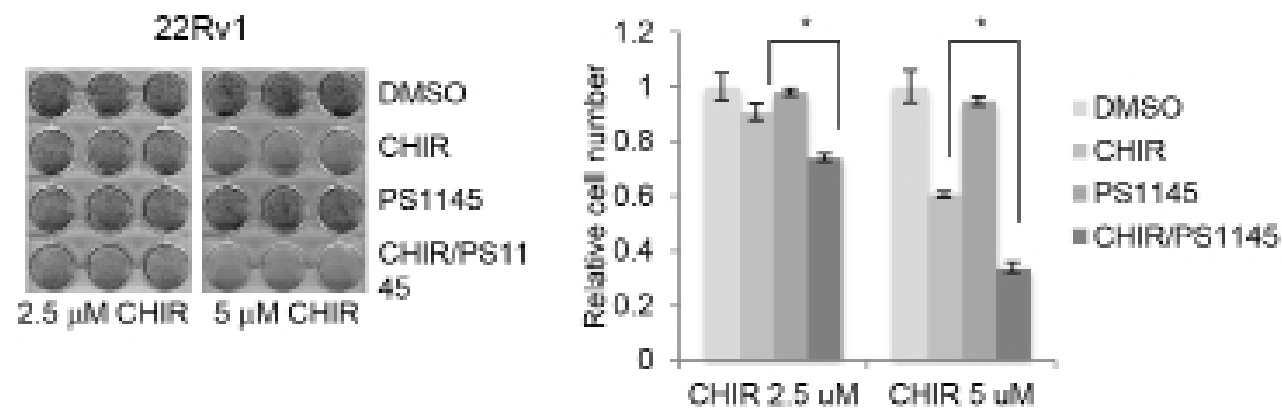

B

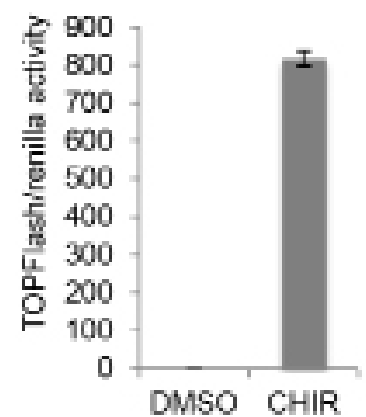

D

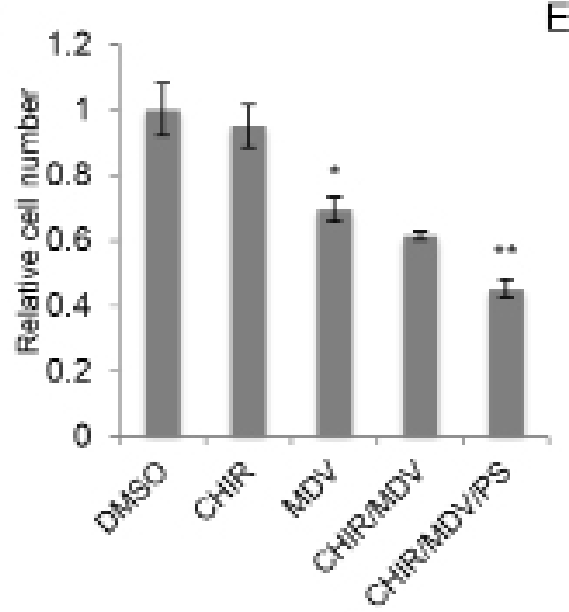

E
C

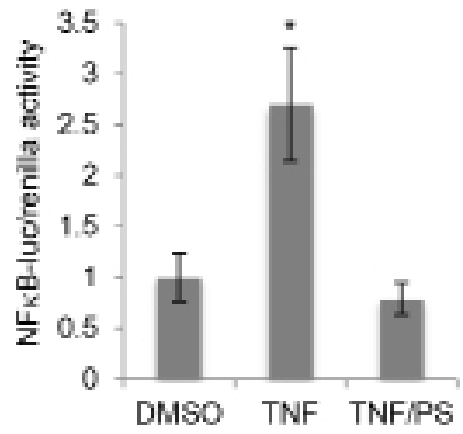

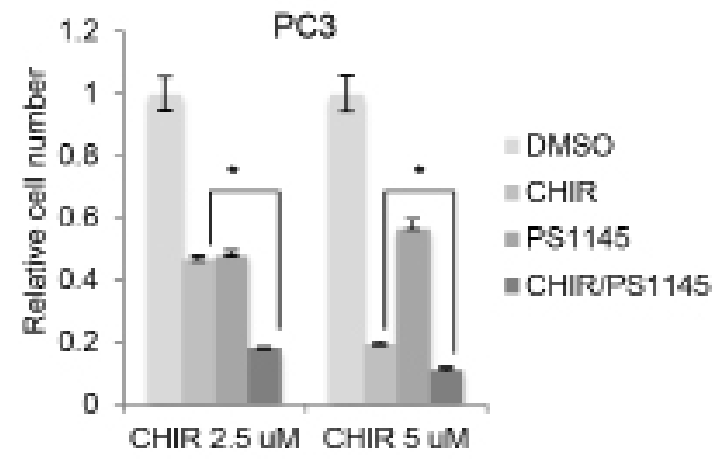

Figure 4: Inhibition of NFKB potentiates the inhibitory effect of CHIR99021 on PCa cell proliferation. (A) Left:

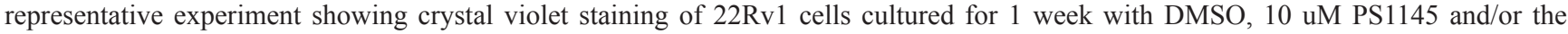
indicated concentrations of CHIR99021 (CHIR). Right: absorbance $(540 \mathrm{~nm}$ ) of solubilized crystal violet was used to calculate relative cell number; ${ }^{*} \mathrm{p}<0.01$. (B) $\beta$-catenin/Tcf-dependent transcriptional activity in $22 \mathrm{Rv} 1$ cells treated with carrier (DMSO) or $5 \mu$ M CHIR99021 (CHIR) was determined by gene reporter assay using Super8xTOPFlash normalized to renilla. (C) NFKB-dependent transcriptional activity in 22Rv1 cells treated with carrier or TNF and $10 \mathrm{uM} \mathrm{PS1145} \mathrm{(PS)} \mathrm{as} \mathrm{determined} \mathrm{by} \mathrm{gene} \mathrm{reporter} \mathrm{assay} \mathrm{using} \mathrm{NFkB-luciferase} \mathrm{normalized}$ to renilla; *p $<0.01$ vs. DMSO. (D) Quantitation of crystal violet assays showing relative cell number for 22Rv1 cells cultured for 1 week in the presence of carrier (DMSO) -/+ 1 uM CHIR99021 (CHIR), 10 uM MDV3310 (MDV) and 10 uM PS1145 (PS); $p<0.05$ versus DMSO $(*)$ and versus MDV $(* *)$. (E) Quantitation of crystal violet assays showing relative cell number for PC 3 cells cultured for 1 week in the presence of DMSO, $10 \mathrm{uM} \mathrm{PS1145}$ and/or the indicated concentrations of CHIR99021 (CHIR); *p $<0.01$.

examined the effects of combined inhibition of GSK-3 and $\mathrm{NF \kappa B}$ in PC3 cells, which do not express AR and have constitutively high NFkB activity. Single treatments with PS1145 and CHIR99021 significantly reduced PC3 cell number, and the combination of both inhibitors had an additive effect (Figure 4E). These results suggest that combined inhibition of GSK-3 and NFkB may also be an effective for androgen-independent $\mathrm{PCa}$.

\section{GSK3 expression is associated with an inverse correlation between $A R$ and $N F \kappa B$ signaling in prostate tumors}

The observed effects of combined inhibition of GSK-3, NFkB and AR prompted us to look for possible links among these signaling pathways in human tumors. To this end, we carried out gene set enrichment analysis 
(GSEA) [36] of human tumors from a previously published database [37]. Tumors were first sorted based on the summed Z-score of the expression levels of a set of genes that is regulated by androgen signaling (AR signature) [38]. Tumors with the highest summed Z-scores were classified as "high AR signature" tumors and those with the lowest values were classified "low AR signature" tumors (Figure 5A). GSEA was then used to examine NFאB pathway activity within these two groups using an $\mathrm{NF \kappa B}$ target gene signature [39]. The NFкB target gene signature was significantly diminished in tumors with the high AR signature, supporting the hypothesis that AR signaling inversely correlates with $\mathrm{NF \kappa B}$ signaling (Figure 5B). This was also observed in an independent tumor dataset [40] (Figure 5C). We next examined NFאB target gene expression levels in tumors with high or low expression of $G S K 3 A$ and $G S K 3 B$. Tumors with a positive Z-score (compared to normal prostates) of both GSK-3 isoform mRNAs were classified as "high GSK-3", and tumors with a negative score for both isoforms were classified as "low GSK-3". Although this classification only reflects GSK-3 mRNA expression (above or below that in normal prostate) and not kinase activity, it revealed that tumors with low GSK-3 expression were enriched for androgen-repressed NFאB target genes (Figures 5D, E). Finally, in order to determine whether expression of the androgen-repressed NFKB target genes identified has prognostic potential in prostate cancer, we analyzed a publicly available patient data set with follow-up data from the cBio Cancer Genomics portal [41]. This revealed that high expression of androgen-repressed NF $\mathrm{B}$ target genes is significantly correlated with reduced survival in patients with metastatic prostate cancer (Figure 6). Together, these findings highlight an inverse correlation between GSK-3/ $\mathrm{AR}$ and NF $\kappa \mathrm{B}$ signaling in patient tumors with potential clinical importance in metastatic prostate cancer.

\section{DISCUSSION}

The involvement of GSK-3 in cancer is complex, with evidence supporting roles for this kinase as a tumor suppressor and a tumor promoter. Further complexity arises from the existence of multiple GSK-3 isoforms with differences in expression, subcellular localization and substrate preference. GSK-3 inhibitors are currently in clinical trials for the treatment of metastatic pancreatic cancer [42], and have the potential to be used to treat several other types of cancer, including PCa. Given the complex responses to GSK-3 in different cell types, it will be important to identify tumor-specific GSK-3 targets as biomarkers for effective treatment. In addition, it is essential to identify targets that may have undesired effects on tumor cell survival or proliferation. The present study reveals that inhibition of GSK-3 in PCa cells leads to activation of $\mathrm{NF} \kappa \mathrm{B}$, and that this reduces the impact of
GSK-3 inhibition on cell proliferation. These observations suggest that combined inhibition of GSK-3 and NFкB may be required for effective inhibition of prostate tumor growth.

In this report we have focused on $\mathrm{NFkB}$ and its relationship with AR. However, our analysis of GSK-3 targets revealed additional potential targets and, in addition, differences between stably silenced and transiently silenced cells that will require further analysis. We noted in our earlier study [1] that while there were no significant differences in growth rates of the stable cell lines in short-term $(72 \mathrm{~h})$ proliferation assays, cell lines with reduced levels of either GSK-3 $\alpha$ or GSK-3 $\beta$ formed fewer colonies than control cells in colony formation assays. Moreover, when colony formation assays were conducted in hormone-depleted medium, GSK-3 $\alpha$ silenced cell lines formed similar numbers of colonies as control cells, whereas GSK-3 $\beta$-silenced cells formed fewer colonies. Those results suggested that chronic silencing of GSK-3 $\alpha$ has an impact on hormone-dependent growth, while chronic silencing of GSK-3 $\beta$ affects both hormone-dependent and hormone-independent growth [1]. However, the mechanisms that underlie the different transcriptional consequences of short-term versus longterm GSK-3 inhibition are not known. One possibility is that stable inhibition of GSK-3 isoforms leads to selection for different cell subsets or types, or changes the proportions of precursor cells in the population. Consistent with this possibility, small molecule inhibition of GSK-3 was recently reported to deplete the population of prostate cancer stem/progenitor-like cells in PC3 and PC $3 \mathrm{M}$ cells, as measured by the proportion of $\mathrm{ALDH}^{\mathrm{HIGH}}$ cells and reduced expression of stem/progenitor markers including NANOG and OCT4 [28]. However, this was not observed in LNCaP C4-2 and DU145 cells. Our analysis of 22Rv1 stem/progenitor cell marker gene expression revealed a small increase in NANOG and reduction in SOX2 in GSK-3 $\alpha$-silenced cells (Figure 1E), inconsistent with selection for prostate cancer stem/progenitor-like cells. Nevertheless, it is interesting to note that treatment of PC3M cells with a small molecule inhibitor of GSK-3 also had opposite effects on expression of NANOG and SOX2. Further studies will be required to determine if changes such as these reflect a change in the proportion of a specific population of progenitor cells.

As outlined in the Introduction, GSK-3 has previously been linked to $\mathrm{NF} \kappa \mathrm{B}$ activation and the mechanisms involved may be highly context-dependent. Our studies found that acute gene silencing and chemical inhibition of GSK-3 increase basal NFKB activity. Inhibition of GSK-3 in serum-starved cells has previously been reported to activate $\mathrm{NF} \kappa \mathrm{B}$ via degradation of $\mathrm{I} \kappa \mathrm{B}$ and nuclear translocation of p65 [19, 43]. This does not appear to be the mechanism in PCa cells, since p65 remained in the cytoplasm in CHIR99021-treated cells (Figure 3F) and inhibition of GSK-3 increased p65-Gal4 


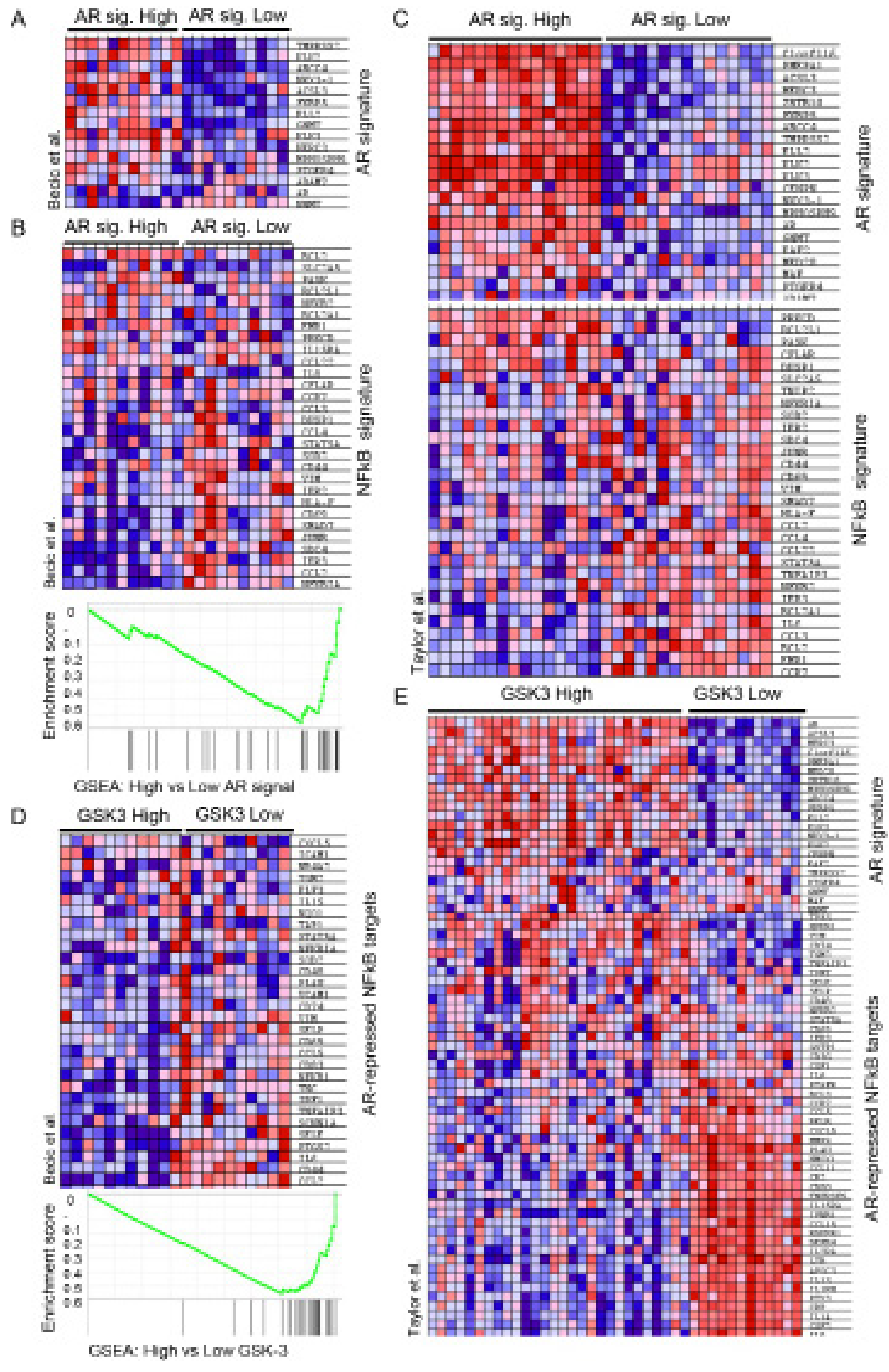

Figure 5: GSK3 expression is associated with an inverse correlation between AR and NFKB signaling in prostate tumors. (A) Heatmap showing the expression of AR target genes in tumors with elevated expression (highest summed Z-score) versus tumors with reduced expression (lowest summed Z-score) of the indicated genes; dataset: Becic-00235 in the CaArray database. (B-E) Gene Set Enrichment Analysis (GSEA) of NFkB target genes in human tumors (B, C) Heatmap and enrichment score of the NFkB gene signature [39] in tumors with elevated expression of AR target genes (highest summed Z-score; high AR signature) versus tumors with reduced expression (lowest summed Z-score; low AR signature); datasets Becic-00235 (B) and GSE21034 (GEO) (C); p < 0.01. (D, E) Heatmap and enrichment score of NFkB-target genes with reduced expression in tumors with elevated androgen signaling (AR-repressed NFkB-targets) in tumors with elevated expression (Z-score $>0.5$; GSK-3 High) versus reduced expression (z-score < 0.5; GSK-3 Low) of both GSK-3 isoforms; datasets Becic-00235 (D) and GSE21034 (GEO) (E); $\mathrm{p}<0.01$. 
activity (Figure 3A), which suggests activation takes place downstream of IKK/I $\mathrm{BB}$. Instead, we observed increased levels of RelB upon GSK-3 inhibition, as has been reported in Jurkat cells, where GSK-3 was found to promote RelB degradation [44]. The importance of RelB in PCa is underlined by its increased expression in high Gleason score tumors [45], and by a study in which gene silencing of RelB reduced PCa cell tumorigenicity [46]. Although we did not detect changes in p65 levels or nuclear localization upon GSK-3 inhibition, the results of the p65-Gal4 reporter assays (Figure 3A) and the gene silencing experiments (Figure 3I) suggest that p65 may play an indirect role in GSK-3 inhibitor-induced NFKB activation. Such a role could result from the known crossregulation of $\mathrm{p} 65$ and RelB signaling, which takes place at several levels [33].

Analysis of AR and NF $\mathrm{BB}$ transcriptional activities in PCa cell lines suggests an inverse association that also correlates with GSK-3. One possibility is that a reduction in GSK-3 signaling activity, for example resulting from loss of PTEN, leads to activation of NFKB, which then inhibits
AR signaling. This would be inconsistent with the view that $\mathrm{NF} \kappa \mathrm{B}$ increases AR expression and/or activity [47-49], although there is also evidence that $\mathrm{NF} \kappa \mathrm{B}$ inhibits $\mathrm{AR}$ in androgen-dependent $\mathrm{PCa}$ [50]. A second possibility is that inhibition of GSK-3 reduces AR activity, which then leads to $\mathrm{NF} \kappa \mathrm{B}$ activation. This would be consistent with our observation and other reports that activation of AR inhibits NFкB [31, 32]. However, the AR antagonist MDV3100 did not increase basal NFKB activity or potentiate GSK-3 inhibitor-mediated $\mathrm{NF} \kappa \mathrm{B}$ activation (Figure $2 \mathrm{~F}$ ), suggesting that this not the case in $22 \mathrm{Rv} 1$ cells. A third possibility is that GSK-3 independently regulates AR and NFאB and their relative activities are determined by the activation state of GSK-3. This possibility would be consistent with the gene expression data, which showed an inverse correlation between androgen- and NFאB-dependent target gene expression in PCa that correlates with GSK-3 mRNA expression. In addition, we observed a correlation of 'androgen-repressed NFאB target' gene expression and reduced survival of patients with metastatic prostate cancer (Figure 6). While this manuscript was in review, a study

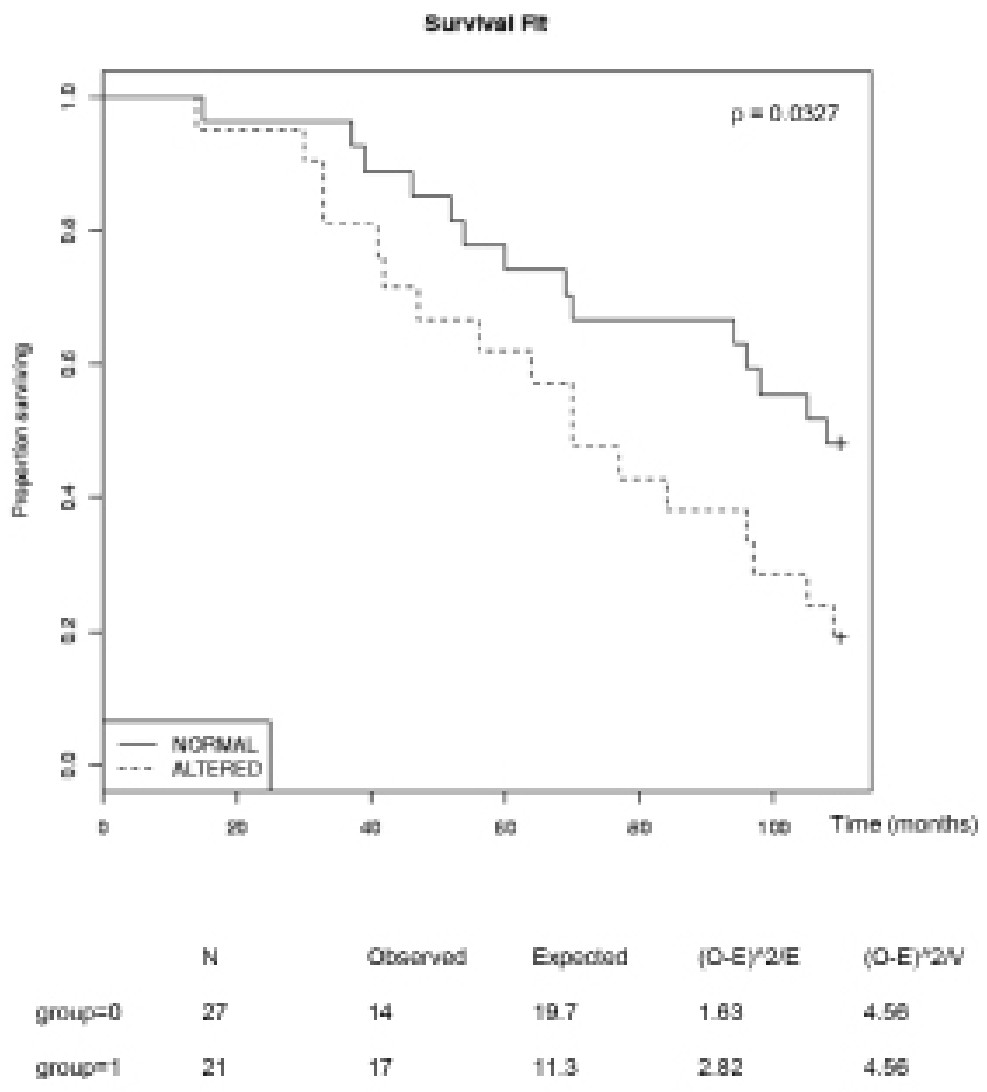

Figure 6: Inverse correlation of survival of patients with metastatic prostate cancer and expression of AR-repressed NFKB-targets. Kaplan Meier plots were obtained from the cBio Cancer Genomics portal, analyzing the Michigan metastatic prostate adenocarcinoma dataset (ref [41]) and the AR-repressed NFאB-targets from Figure 5 (CSF1, IL6, PTAFR, BCL3, CCR7, CCL5, RELB, CXCL5, MMP9, PLAU, HMOX1, CCL11, CR2, CD80, TNFRSF9, IL15RA, IFNB1, CCL15, BDKRB1, IL2RA, LTB, APOC3, IL13, IL1RN, $P T X 3, C R P, I L 1 A, C S F 2$ and $I L 9)$. Statistical significance of the whole sample was determined with the Log Rank test at 100 months $\mathrm{p}=0.0327$; Chi-Square test $=4.6$ on 1 degree of freedom. 
was published of the effects of increased NFKB activity and androgen-depletion on gene expression in non-tumorigenic mouse prostates. This led to the identification of a gene expression signature that predicted disease-specific survival and distant metastases-free survival in patients with $\mathrm{PCa}$ [51]. Intriguingly, the genes in that signature do not show any overlap with the genes we analyzed here. Further studies will be required to establish if these tumor signatures arise from specific misregulation of NFKB- and androgendependent signaling in a subset of tumor cells, or from tumors of different cellular compositions.

Our results suggest that combining GSK-3, AR and $\mathrm{NF} \kappa \mathrm{B}$ inhibitors will provide a more effective therapy than single agents for the treatment of some prostate tumors. A combination of GSK-3 and NFkB inhibitors was recently proposed for treatment of osteosarcoma [52]. In this example, however, inhibition of GSK-3 reduced $\mathrm{NF} \kappa \mathrm{B}$ activity, once again underlining the contextdependent nature of the link between GSK-3 and NFкB signaling. Importantly, since silencing GSK-3 $\alpha$ alone reduces $A R$ activity without activating $N F \kappa B$, our results support the case for the development and sequential use of isoform-specific GSK-3 inhibitors [53] to treat different stages of PCa.

\section{METHODS}

\section{Cell culture and proliferation assays}

22Rv1 cells (ATCC) were cultured in RPMI 1640/ DMEM (1:1) (Invitrogen) supplemented with 20\% FCS and antibiotics (100 U/ml penicillin, $100 \mu \mathrm{g} / \mathrm{ml}$ streptomycin) at $37^{\circ} \mathrm{C}$ and $5 \% \mathrm{CO}_{2} . \mathrm{LNCaP}$ and $\mathrm{PC} 3$ cells (ATCC) were cultured in RPMI 1640 supplemented with $10 \%$ FCS and antibiotics. Cells were passaged when they reached $70-80 \%$ confluence at $1: 5-6$ using $0.05 \%$ trypsin. For proliferation assays, cells were seeded at a density of 1,000 cells $/ \mathrm{cm}^{2}$ in triplicate in 12-well plates and inhibitors or an equal volume of carrier were added the next day. Media were replaced and fresh inhibitors added every other day for 7 days. Cells were then rinsed with PBS, stained with crystal violet, rinsed again, airdried and images acquired. In some experiments, crystal violet was subsequently solubilized in $10 \%$ acetic acid and absorbance measured at $590 \mathrm{~nm}$. The GSK-3 inhibitors CHIR99021 (Axon Medchem and Calbiochem) and BIOacetoxime (Merck), the IKK inhibitor PS1145 (Sigma) and the AR inhibitor MDV3100 (Selleck Chemicals LLC) were all dissolved in DMSO. TNF (R\&D) was dissolved in PBS $+0.1 \%$ BSA and DHT (Sigma) in ethanol.

\section{RNA analysis}

Reverse transcription was performed on 1 ug of total RNA using M-MLV Reverse Transcriptase and RNase
OUT Ribonuclease Inhibitor (Invitrogen), according to manufacturer's instructions. Quantitative-PCR was performed using PerfeCTa Sybr Green Supermix, Low Rox (Quanta, Barcelona, Spain) in a Viia7 RealTime PCR System (Applied Biosystems). The primer sequences were previously described [54-56], apart from GSK3A AGGTCCCCAGCGGGCACTAC, GGGTAGGTGTGGCATCGGTCG; GSK3B GTCCTGGGAACTCCAACAAGGG, GTGAAATGTCCTGTTCCTGAC; TFAP2A ACGTTACCCTGCTCACATCAC, CAGGAAATTCGGTTTCGCACA. Relative fold changes in mRNA were determined according to the $\Delta \Delta \mathrm{Ct}$ method, relative to the housekeeping gene 36B4, and intraexperimental standard deviation (s.d.) was calculated according to Bookout and Mangelsdorf [57]. Statistical significance was calculated from three independent experiments using Student's t test.

\section{Plasmids and transfections}

Plasmids for $\beta$-catenin (pmT23 $\beta$-catenin) [58], pSM2c GSK-3 $\alpha$ ( $\alpha$ sh1 and $\alpha$ sh2), GSK-3 $\beta$ ( $\beta$ sh1 and $\beta$ sh2) and control shRNA plasmid (Open Biosystems, Madrid, Spain) [59, 60], RelA, RelB and c-Rel shRNAs [35] (from B. Lewis (NCI, Bethesda, MA, USA) and pSUPER-Retro-puro control shRNA [61] (from A. Carracedo, CIC bioGUNE) were previously described. Gene reporter assays were carried out using NFkBluciferase (Clontech), pGal4, pGal4-p65 [62] and Gal4luciferase (from the BCCM/LMBP, Ghent University/ Lienhard Schmitz, Institute of Biochemistry, University of Giessen), pRL-TK (Promega), MMTV-luciferase (from C. Bevan, Imperial College London) and Super8xTOP/ FOPFlash [63] (from R. Moon, University of Washington, Seattle). Cells were plated at a density of $50,000 \mathrm{cells} / \mathrm{cm}^{2}$ (22Rv1) or $25,000 \mathrm{cells} / \mathrm{cm}^{2}$ in 24-well plates and 24-48 hours later transfected using $1 \mu \mathrm{l}$ of Lipofectamine, $2 \mu \mathrm{l}$ of Plus reagent, $100 \mathrm{ng}$ of firefly luciferase reporter, $0.5 \mathrm{ng}$ pGal4/pGal4-p65 (where indicated), 15 ng of pRL-TK and up to $200 \mathrm{ng}$ (unless otherwise indicated) of shRNA or expression plasmids, according to manufacturer's instructions (Invitrogen). Luciferase activity was measured with the DualGlo Stop\&Glo luciferase assay system (Promega). For experiments using MMTV-luciferase, cells were cultured in phenol red-free RPMI and 10\% charcoalstripped serum.

\section{Transcription factor binding screen}

Cells were rinsed in PBS and nuclear extracts were prepared using the Nuclear Extraction Kit (Panomics). $5 \mu \mathrm{g}$ of nuclear extract was used for hybridization with the TranSignal $^{\text {TM }}$ Protein/DNA Array I (Panomics), according to manufacturer's instructions. In brief, nuclear extracts 
were incubated with a pool of biotin-labeled transcription factor (TF) binding probes, and DNA/TF complexes were isolated using an ion-exchange column. Finally, the isolated DNA probes were hybridized to membranes containing complementary TF binding site sequences and bound probes were visualized using an HRP-conjugated anti-biotin antibody. Quantitation was done by selecting non-saturated exposures of high-resolution scans of the membranes, grid circles and calculating the average signal using ImageJ software, using negative controls as a blank and taking the average signal from the row of positive controls for each membrane to normalize the data for each membrane. Binding assay experiments were carried out at least twice each, and, in the case of the stable lines, using two different shRNAs for each GSK-3 isoform.

\section{Western blotting}

Cells were rinsed in PBS and lysed in RIPA (radioimmunoprecipitation assay) lysis buffer (19) containing Complete ${ }^{\mathrm{TM}}$ Protease Inhibitor Cocktail (Roche) and PhosSTOP Phosphatase Inhibitor Cocktail (Roche) on ice for 15 minutes, cleared by centrifugation and used directly or frozen on dry ice for later use. $20 \mu \mathrm{g}$ of lysate was resolved on $8 \%$ or $10 \%$ SDS polyacrylamide gels, transferred to nitrocellulose membranes (Whatman). Nonspecific binding was blocked using 3\% BSA/TBST (TBS with $0.05 \%$ Tween-20), and blots were probed overnight at $4^{\circ} \mathrm{C}$ with primary antibodies. Blots were washed in TBST and antigens were detected using HRP-conjugated secondary antibodies as previously described $[1,59]$. Primary antibodies, diluted 1:1000, were to GSK-3 $\alpha$ (Santa Cruz Biotechnology sc-5264), GSK-3 $\beta$ (BD Biosciences 610202), HSP60 (Santa Cruz Biotechnology), GAPDH (Sigma), and to NFkB p65 (D14E12), RelB (C1E4), c-Rel, p105/p50 and p100/p52 (18D10) (all Cell Signaling).

\section{Immunofluorescence}

Cells were plated on gelatin-coated glass coverslips $48 \mathrm{~h}$ before transfection. Cells were fixed for $15 \mathrm{~min}$ in $4 \%$ PFA, permeabilized with $0.1 \%$ Triton for $10 \mathrm{~min}$, incubated for $1 \mathrm{~h}$ with blocking buffer (50 mM glycine, $2 \%$ BSA, $0.01 \%$ Na-azide in PBS) to block nonspecific binding and probed for $2 \mathrm{~h}$ with primary antibodies diluted in wash buffer (blocking buffer 1:10 in PBS). Primary antibodies used were to GSK-3 $\alpha$ (1:500, Santa Cruz Biotechnology sc-5264), GSK-3 $\beta$ (1:500, BD Biosciences 610202), p65 (1:200, Santa Cruz Biotechnology) and p100/52 (1:250, Abcam). Immune complexes were detected with appropriate Alexa488- or Alexa594-congugated secondary antibodies (Invitrogen) diluted 1:500 in wash buffer and mounted using Vectashield ${ }^{\circledR}$ (Vector Labs), and DAPI (diamidino-2-phenylindole) was used to stain nuclei. Confocal images were acquired as previously described [59] with an SP2 microscope station (Leica) using a 63 x 1.3 NA lens.

\section{Analysis of microarray data}

The human prostate cancer gene expression datasets used (Becic [37]; Taylor [40]) are available at caArray (https://array.nci.nih.gov/caarray/home. action) and cBio Cancer Genomics (www.cbioportal. org/public-portal/), respectively. Cell files containing raw data were normalized with RMAExpress (Robust Multichip Average) software, and chips with normalized unscaled standard error (NUSE) or relative log expression (RLE) values 1.5 IQR (interquartile range) above the upper quartile or 1.5 IQR below the lower quartile were discarded in further analysis. The intensity of the androgen-responsive-gene signature [38] was then scored using the $\mathrm{Z}$-score values calculated for the genes included in the signature, and those tumors with highest or lowest added Z-score were classified as high or low AR-signature, respectively. Similarly, the Z-score was calculated for GSK3A and GSK3B and tumors with a Z-score value of GSK3A and GSK3B $>0.5$ were classified high total GSK3, and tumors with a Z-value $<-0.5$ for both isoforms were classified as low total GSK3. Gene set enrichment analysis (GSEA) [36] was performed with the normalized gene expression values from the tumors classified as above (high vs. low AR signature; high vs. low GSK3), and the level of enrichment of the NFKB signature [39] was calculated using Student's $t$ test on the collapsed probe sets and running 1000 permutations. Kaplan Meier plots were obtained from cBio Cancer Genomics portal analyzing the Michigan metastatic prostate adenocarcinoma dataset [41]. Statistical significance of the whole sample was determined with the log rank test both at 100 months and 220 months, with the former found to be significant.

\section{ACKNOWLEDGEMENTS}

We thank Lienhard Schmitz (University of Giessen), Brian Lewis (National Cancer Institute, Bethesda), and Arkaitz Carracedo (CIC bioGUNE) for plasmids, and Maria Vivanco (CIC bioGUNE) for reading the manuscript.

\section{FOOTNOTES}

This study was funded by grants from the Spanish Ministry of Science and Innovation (SAF 2008-00768; SAF2011-30494), the Prostate Cancer Research Foundation (now PCUK) and the Department of Industry, Tourism and Trade (Etortek) and Department of Innovation Technology of the Government of the Autonomous Community of the Basque Country. 


\section{REFERENCES}

1. Darrington RS, Campa VM, Walker MM, BengoaVergniory N, Gorrono-Etxebarria I, Uysal-Onganer P, Kawano Y, Waxman J and Kypta RM. Distinct expression and activity of GSK-3alpha and GSK-3beta in prostate cancer. Int J Cancer. 2012; 131(6):E872-883.

2. Li R, Erdamar S, Dai H, Sayeeduddin M, Frolov A, Wheeler TM and Ayala GE. Cytoplasmic accumulation of glycogen synthase kinase-3beta is associated with aggressive clinicopathological features in human prostate cancer. Anticancer Res. 2009; 29(6):2077-2081.

3. McCubrey JA, Steelman LS, Bertrand FE, Davis NM, Abrams SL, Montalto G, D'Assoro AB, Libra M, Nicoletti F, Maestro R, Basecke J, Cocco L, Cervello M and Martelli AM. Multifaceted roles of GSK-3 and Wnt/beta-catenin in hematopoiesis and leukemogenesis: opportunities for therapeutic intervention. Leukemia. 2014; 28(1):15-33.

4. Mazor M, Kawano Y, Zhu H, Waxman J and Kypta RM. Inhibition of glycogen synthase kinase-3 represses androgen receptor activity and prostate cancer cell growth. Oncogene. 2004; 23(47):7882-7892.

5. Schutz SV, Schrader AJ, Zengerling F, Genze F, Cronauer MV and Schrader M. Inhibition of glycogen synthase kinase3beta counteracts ligand-independent activity of the androgen receptor in castration resistant prostate cancer. PLoS One. 2011; 6(9):e25341.

6. Zhu Q, Yang J, Han S, Liu J, Holzbeierlein J, Thrasher JB and $\mathrm{Li}$ B. Suppression of glycogen synthase kinase 3 activity reduces tumor growth of prostate cancer in vivo. Prostate. 2011; 71(8):835-845.

7. Chen Y, Sawyers CL and Scher HI. Targeting the androgen receptor pathway in prostate cancer. Curr Opin Pharmacol. 2008; 8(4):440-448.

8. Gioeli D and Paschal BM. Post-translational modification of the androgen receptor. Mol Cell Endocrinol. 2012; 352(1-2):70-78.

9. Liao X, Thrasher JB, Holzbeierlein J, Stanley S and Li B. Glycogen synthase kinase-3beta activity is required for androgen-stimulated gene expression in prostate cancer. Endocrinology. 2004; 145(6):2941-2949.

10. Salas TR, Kim J, Vakar-Lopez F, Sabichi AL, Troncoso P, Jenster G, Kikuchi A, Chen SY, Shemshedini L, Suraokar M, Logothetis CJ, DiGiovanni J, Lippman SM and Menter DG. Glycogen synthase kinase- 3 beta is involved in the phosphorylation and suppression of androgen receptor activity. J Biol Chem. 2004; 279(18):19191-19200.

11. Wang L, Lin HK, Hu YC, Xie S, Yang L and Chang C. Suppression of androgen receptor-mediated transactivation and cell growth by the glycogen synthase kinase 3 beta in prostate cells. J Biol Chem. 2004; 279(31):32444-32452.

12. Schutz SV, Cronauer MV and Rinnab L. Inhibition of glycogen synthase kinase-3beta promotes nuclear export of the androgen receptor through a CRM1-dependent mechanism in prostate cancer cell lines. J Cell Biochem. 2010; 109(6):1192-1200.

13. Yang J, Takahashi Y, Cheng E, Liu J, Terranova PF, Zhao B, Thrasher JB, Wang HG and Li B. GSK-3beta promotes cell survival by modulating Bif-1-dependent autophagy and cell death. J Cell Sci. 2010; 123(Pt 6):861-870.

14. Goc A, Al-Husein B, Katsanevas K, Steinbach A, Lou U, Sabbineni H, DeRemer DL and Somanath PR. Targeting Src-mediated Tyr216 phosphorylation and activation of GSK-3 in prostate cancer cells inhibit prostate cancer progression in vitro and in vivo. Oncotarget. 2014; 5(3):775-787.

15. Du Q and Geller DA. Cross-Regulation Between Wnt and NF-kappaB Signaling Pathways. For Immunopathol Dis Therap. 2010; 1(3):155-181.

16. Doble BW, Patel S, Wood GA, Kockeritz LK and Woodgett JR. Functional redundancy of GSK-3alpha and GSK-3beta in Wnt/beta-catenin signaling shown by using an allelic series of embryonic stem cell lines. Dev Cell. 2007; 12(6):957-971.

17. Cho J, Rameshwar P and Sadoshima J. Distinct roles of glycogen synthase kinase (GSK)-3alpha and GSK-3beta in mediating cardiomyocyte differentiation in murine bone marrow-derived mesenchymal stem cells. J Biol Chem. 2009; 284(52):36647-36658.

18. Liang MH and Chuang DM. Differential roles of glycogen synthase kinase-3 isoforms in the regulation of transcriptional activation. J Biol Chem. 2006; 281(41):30479-30484.

19. Graham JR, Tullai JW and Cooper GM. GSK-3 represses growth factor-inducible genes by inhibiting NF-kappaB in quiescent cells. J Biol Chem. 2009; 285(7):4472-4480.

20. Buss H, Dorrie A, Schmitz ML, Frank R, Livingstone M, Resch K and Kracht M. Phosphorylation of serine 468 by GSK-3beta negatively regulates basal p65 NF-kappaB activity. J Biol Chem. 2004; 279(48):49571-49574.

21. Demarchi F, Bertoli C, Sandy P and Schneider C. Glycogen synthase kinase-3 beta regulates NF-kappa B1/p105 stability. J Biol Chem. 2003; 278(41):39583-39590.

22. Park SH, Park-Min KH, Chen J, Hu X and Ivashkiv LB. Tumor necrosis factor induces GSK3 kinase-mediated cross-tolerance to endotoxin in macrophages. Nat Immunol. 12(7):607-615.

23. Sanchez JF, Sniderhan LF, Williamson AL, Fan S, Chakraborty-Sett S and Maggirwar SB. Glycogen synthase kinase 3beta-mediated apoptosis of primary cortical astrocytes involves inhibition of nuclear factor kappaB signaling. Mol Cell Biol. 2003; 23(13):4649-4662.

24. Hoeflich KP, Luo J, RubieEA, Tsao MS, Jin O and Woodgett JR. Requirement for glycogen synthase kinase-3beta in cell survival and NF-kappaB activation. Nature. 2000; 406(6791):86-90.

25. Steinbrecher KA, Wilson W, 3rd, Cogswell PC and Baldwin AS. Glycogen synthase kinase 3 beta functions to 
specify gene-specific, NF-kappaB-dependent transcription. Mol Cell Biol. 2005; 25(19):8444-8455.

26. Itoh S, Saito T, Hirata M, Ushita M, Ikeda T, Woodgett JR, Algul H, Schmid RM, Chung UI and Kawaguchi H. GSK-3alpha and GSK-3beta proteins are involved in early stages of chondrocyte differentiation with functional redundancy through RelA protein phosphorylation. J Biol Chem. 2012; 287(35):29227-29236.

27. Li H, Xu LL, Masuda K, Raymundo E, McLeod DG, Dobi A and Srivastava S. A feedback loop between the androgen receptor and a NEDD4-binding protein, PMEPA1, in prostate cancer cells. J Biol Chem. 2008; 283(43):28988-28995.

28. Kroon J, in't Veld LS, Buijs JT, Cheung H, van der Horst $\mathrm{G}$ and van der Pluijm G. Glycogen synthase kinase- $3 \beta$ inhibition depletes the population of prostate cancer stem/ progenitor-like cells and attenuates metastatic growth. Oncotarget. 2014; [advance online publication].

29. Liu T, Xu F, Du X, Lai D, Liu T, Zhao Y, Huang Q, Jiang L, Huang W, Cheng W and Liu Z. Establishment and characterization of multi-drug resistant, prostate carcinomainitiating stem-like cells from human prostate cancer cell lines 22RV1. Molecular and cellular biochemistry. 2010; 340(1-2):265-273.

30. Bain J, Plater L, Elliott M, Shpiro N, Hastie CJ, McLauchlan H, Klevernic I, Arthur JS, Alessi DR and Cohen P. The selectivity of protein kinase inhibitors: a further update. Biochem J. 2007; 408(3):297-315.

31. Altuwaijri S, Lin HK, Chuang KH, Lin WJ, Yeh S, Hanchett LA, Rahman MM, Kang HY, Tsai MY, Zhang Y, Yang $\mathrm{L}$ and Chang $\mathrm{C}$. Interruption of nuclear factor kappaB signaling by the androgen receptor facilitates 12-O-tetradecanoylphorbolacetate-induced apoptosis in androgen-sensitive prostate cancer LNCaP cells. Cancer Res. 2003; 63(21):7106-7112.

32. Nelius T, Filleur S, Yemelyanov A, Budunova I, Shroff E, Mirochnik Y, Aurora A, Veliceasa D, Xiao W, Wang Z and Volpert OV. Androgen receptor targets NFkappaB and TSP1 to suppress prostate tumor growth in vivo. Int J Cancer. 2007; 121(5):999-1008.

33. Shih VF, Tsui R, Caldwell A and Hoffmann A. A single NFkappaB system for both canonical and non-canonical signaling. Cell Res. 2011; 21(1):86-102.

34. Mayo MW, Madrid LV, Westerheide SD, Jones DR, Yuan XJ, Baldwin AS, Jr, and Whang YE. PTEN blocks tumor necrosis factor-induced NF-kappa B-dependent transcription by inhibiting the transactivation potential of the p65 subunit. J Biol Chem. 2002; 277(13):11116-11125.

35. Ranuncolo SM, Pittaluga S, Evbuomwan MO, Jaffe ES and Lewis BA. Hodgkin lymphoma requires stabilized NIK and constitutive RelB expression for survival. Blood. 2012; 120(18):3756-3763.

36. Subramanian A, Tamayo P, Mootha VK, Mukherjee S, Ebert BL, Gillette MA, Paulovich A, Pomeroy SL, Golub TR, Lander ES and Mesirov JP. Gene set enrichment analysis: a knowledge-based approach for interpreting genomewide expression profiles. Proc Natl Acad Sci U S A. 2005; 102(43):15545-15550.

37. Yu YP, Landsittel D, Jing L, Nelson J, Ren B, Liu L, McDonald C, Thomas R, Dhir R, Finkelstein S, Michalopoulos G, Becich M and Luo JH. Gene expression alterations in prostate cancer predicting tumor aggression and preceding development of malignancy. J Clin Oncol. 2004; 22(14):2790-2799.

38. Hieronymus H, Lamb J, Ross KN, Peng XP, Clement C, Rodina A, Nieto M, Du J, Stegmaier K, Raj SM, Maloney KN, Clardy J, Hahn WC, Chiosis G and Golub TR. Gene expression signature-based chemical genomic prediction identifies a novel class of HSP90 pathway modulators. Cancer Cell. 2006; 10(4):321-330.

39. Feuerhake F, Kutok JL, Monti S, Chen W, LaCasce AS, Cattoretti G, Kurtin P, Pinkus GS, de Leval L, Harris NL, Savage KJ, Neuberg D, Habermann TM, Dalla-Favera R, Golub TR and Aster JC. NFkappaB activity, function, and target-gene signatures in primary mediastinal large B-cell lymphoma and diffuse large B-cell lymphoma subtypes. Blood. 2005; 106(4):1392-1399.

40. Taylor BS, Schultz N, Hieronymus H, Gopalan A, Xiao Y, Carver BS, Arora VK, Kaushik P, Cerami E, Reva B, Antipin Y, Mitsiades N, Landers T, Dolgalev I, Major JE and Wilson M. Integrative genomic profiling of human prostate cancer. Cancer Cell. 2010; 18(1):11-22.

41. Grasso CS, Wu YM, Robinson DR, Cao X, Dhanasekaran SM, Khan AP, Quist MJ, Jing X, Lonigro RJ, Brenner JC, Asangani IA, Ateeq B, Chun SY, Siddiqui J, Sam L and Anstett M. The mutational landscape of lethal castration-resistant prostate cancer. Nature. 2012; 487(7406):239-243.

42. Zamek-Gliszczynski MJ, Abraham TL, Alberts JJ, Kulanthaivel P, Jackson KA, Chow KH, McCann DJ, Hu H, Anderson S, Furr NA, Barbuch RJ and Cassidy KC. Pharmacokinetics, metabolism, and excretion of the glycogen synthase kinase-3 inhibitor LY2090314 in rats, dogs, and humans: a case study in rapid clearance by extensive metabolism with low circulating metabolite exposure. Drug Metab Dispos. 2013; 41(4):714-726.

43. Bachelder RE, Yoon SO, Franci C, de Herreros AG and Mercurio AM. Glycogen synthase kinase-3 is an endogenous inhibitor of Snail transcription: implications for the epithelial-mesenchymal transition. J Cell Biol. 2005; 168(1):29-33.

44. Neumann M, Klar S, Wilisch-Neumann A, Hollenbach E, Kavuri S, Leverkus M, Kandolf R, Brunner-Weinzierl MC and Klingel K. Glycogen synthase kinase-3beta is a crucial mediator of signal-induced RelB degradation. Oncogene. 2011; 30(21):2485-2492.

45. Lessard L, Begin LR, Gleave ME, Mes-Masson AM and Saad F. Nuclear localisation of nuclear factor-kappaB transcription factors in prostate cancer: an immunohistochemical study. Br J Cancer. 2005; 93(9):1019-1023. 
46. Xu Y, Josson S, Fang F, Oberley TD, St Clair DK, Wan XS, Sun Y, Bakthavatchalu V, Muthuswamy A and St Clair WH. RelB enhances prostate cancer growth: implications for the role of the nuclear factor-kappaB alternative pathway in tumorigenicity. Cancer Res. 2009; 69(8):3267-3271.

47. Zhang L, Altuwaijri S, Deng F, Chen L, Lal P, Bhanot UK, Korets R, Wenske S, Lilja HG, Chang C, Scher HI and Gerald WL. NF-kappaB regulates androgen receptor expression and prostate cancer growth. Am J Pathol. 2009; 175(2):489-499.

48. Nadiminty N, Lou W, Sun M, Chen J, Yue J, Kung HJ, Evans CP, Zhou Q and Gao AC. Aberrant activation of the androgen receptor by NF-kappaB2/p52 in prostate cancer cells. Cancer Res. 2010; 70(8):3309-3319.

49. Jin RJ, Lho Y, Connelly L, Wang Y, Yu X, Saint Jean L, Case TC, Ellwood-Yen K, Sawyers CL, Bhowmick NA, Blackwell TS, Yull FE and Matusik RJ. The nuclear factorkappaB pathway controls the progression of prostate cancer to androgen-independent growth. Cancer Res. 2008; 68(16):6762-6769.

50. Ko S, Shi L, Kim S, Song CS and Chatterjee B. Interplay of nuclear factor-kappaB and B-myb in the negative regulation of androgen receptor expression by tumor necrosis factor alpha. Mol Endocrinol. 2008; 22(2):273-286.

51. Jin R, Yi Y, Yull FE, Blackwell TS, Clark PE, Koyama T, Smith JA, Jr, and Matusik RJ. NF-kappaB gene signature predicts prostate cancer progression. Cancer Res. 2014; 74(10):2763-2772.

52. Tang QL, Xie XB, Wang J, Chen Q, Han AJ, Zou CY, Yin JQ, Liu DW, Liang Y, Zhao ZQ, Yong BC, Zhang RH, Feng QS, Deng WG, Zhu XF and Zhou BP. Glycogen synthase kinase-3beta, NF-kappaB signaling, and tumorigenesis of human osteosarcoma. J Natl Cancer Inst. 2012; 104(10):749-763.

53. Lo Monte F, Kramer T, Gu J, Anumala UR, Marinelli L, La Pietra V, Novellino E, Franco B, Demedts D, Van Leuven F, Fuertes A, Dominguez JM, Plotkin B, Eldar-Finkelman $\mathrm{H}$ and Schmidt B. Identification of glycogen synthase kinase- 3 inhibitors with a selective sting for glycogen synthase kinase-3alpha. J Med Chem. 2012; 55(9):4407-4424.
54. Piva M, Domenici G, Iriondo O, Rabano M, Simoes BM, Comaills V, Barredo I, Lopez-Ruiz JA, Zabalza I, Kypta R and Vivanco M. Sox2 promotes tamoxifen resistance in breast cancer cells. EMBO molecular medicine. 2014; 6(1):66-79.

55. Romero D, Kawano Y, Bengoa N, Walker MM, Maltry N, Niehrs C, Waxman J and Kypta R. Downregulation of Dickkopf-3 disrupts prostate acinar morphogenesis through TGF-beta/Smad signalling. J Cell Sci. 2013; 126(Pt 8):1858-1867.

56. Alfonso RJ, Gorrono-Etxebarria I, Rabano M, Vivanco MD and Kypta R. Dickkopf-3 alters the morphological response to retinoic acid during neuronal differentiation of human embryonal carcinoma cells. Developmental neurobiology. 2014

57. Bookout AL and Mangelsdorf DJ. Quantitative real-time PCR protocol for analysis of nuclear receptor signaling pathways. Nucl Recept Signal. 2003; 1:e012.

58. Giannini AL, Vivanco M and Kypta RM. alpha-catenin inhibits beta-catenin signaling by preventing formation of a beta-catenin*T-cell factor*DNA complex. J Biol Chem. 2000; 275(29):21883-21888.

59. Campa VM and Kypta RM. Issues associated with the use of phosphospecific antibodies to localise active and inactive pools of GSK-3 in cells. Biol Direct. 2011; 6:4.

60. Castano Z, Gordon-Weeks PR and Kypta RM. The neuron-specific isoform of glycogen synthase kinase-3beta is required for axon growth. J Neurochem. 2010; 113(1):117-130.

61. Chen Z, Trotman LC, Shaffer D, Lin HK, Dotan ZA, Niki M, Koutcher JA, Scher HI, Ludwig T, Gerald W, Cordon-Cardo $\mathrm{C}$ and Pandolfi PP. Crucial role of p53-dependent cellular senescence in suppression of Pten-deficient tumorigenesis. Nature. 2005; 436(7051):725-730.

62. Schmitz ML and Baeuerle PA. The p65 subunit is responsible for the strong transcription activating potential of NF-kappa B. Embo J. 1991; 10(12):3805-3817.

63. Veeman MT, Slusarski DC, Kaykas A, Louie SH and Moon RT. Zebrafish prickle, a modulator of noncanonical Wnt/Fz signaling, regulates gastrulation movements. Curr Biol. 2003; 13(8):680-685. 